\title{
PENERAPAN TEMATIK NYANYIAN MANTAU KE DALAM BENTUK LAGU DUA BAGIAN "MANTAU"
}

\author{
Ana Dilla Putri \\ Penciptaan dan Pengkajian Seni, Program Pascasarjana \\ Institut Seni Indonesia Padangpanjang \\ Jl. Bahder Johan, Guguak Malintang, Padangpanjang, Kota Padangpanjang, 27126. \\ Sumatera Barat. Indonesia. \\ Email: anadilla.putri49@gmail.com
}

\begin{abstract}
Abstrak
Kesenian Mantau merupakan salah satu kesenian tradisi yang tumbuh dan berkembang di daerah Kecamatan Bangko Kabupaten Merangin Provinsi Jambi yang berbentuk nyanyian atau vokal tradisional yang dibawakan oleh satu orang penyanyi. Selain mempunyai vokal yang mempuni, penyanyi Mantau mesti memiliki kemampuan dalam menyampaikan syair-syair lagu yang tersusun dalam bentuk pantun secara spontan sesuai dengan keadaan atau kejadian setempat. Selain itu, terdapat keunikan dalam kesenian Mantau yang mana karakteristik dari melodi Mantau yang cenderung memakai material mixolidya modes dinyanyikan dengan teknik rubato dan ad libitum. Tujuan dari penciptaan musik yang diolah dan dikembangkan dengan format orchestra. Metode yang digunakan dalam proses penciptaan komposisi musik ini yaitu eksplorasi, improvisasi atau eksperimen dan pembentukan.
\end{abstract}

Kata Kunci: Mantau, Mixolidyan modes, Komposisi, Orkestra.

\begin{abstract}
The art of Mantau is one of the traditional music that grows and delops in the area of Bangko Subdistrict, Merangin Regency, Jambi Province in the form of traditional singing or vocal performed by one singer. In addition to possessing vocal abilities, the singer Mantau must have to ability to deliver poems arranged in the form of poetry spontaneously according to local circumstances or events. In addition, there is a unique in Mantau art which is a characteristic of Mantau melodies that tend to uses mixolidyan modes material sung with rubato and ad libitum technique. The puspose of creating this composition is to demonstrate the composition of musical composition that are processed and developed in the orchestra format. The method used in the process of creating this musical composition is exploration, impovisation, experimentation, and formation.
\end{abstract}

Keyword : Mantau; Mixolidyan modes; Composition; Orchetra. 


\section{PENDAHULUAN}

Kesenian Mantau merupakan salah satu kesenian tradisi yang tumbuh dan berkembang di daerah Kecamatan Bangko Kabupaten Merangin Provinsi Jambi yang berbentuk nyanyian atau vokal tradisional yang dibawakan oleh satu orang penyanyi. Selain mempunyai kemampuan vokal yang mempuni, penyanyi Mantau mesti memiliki kemampuan dalam menyampaikan syairsyair lagu yang tersusun dalam bentuk pantun secara spontan sesuai dengan keadaan atau kejadian setempat. Oleh demikian, maka kemampuan bernyanyi dan spontanitas berpantun menjadi tuntutan tersendiri bagi seorang penyanyi di dalam kesenian Mantau.

Mantau pada dasarnya memiliki ciri khas yang tergambar pada isi syair Mantau yang lebih cenderung menceritakan kejadian orang lain atau lebih kepada hubungan sosial masyarakat. Ditinjau dari aspek musikal dapat digambarkan juga bahwa terdapat aksentuasi-aksentuasi yang dibawakan oleh penyanyi Mantau, tepatnya sebelum teks pantun dinyanyikan.

Dahulunya, masyarakat Bangko menjadikan Mantau sebagai hiburan yang dinikmati secara pribadi. Namun seiring perkembangan zaman, Mantau mengalami perubahan. Saat ini Mantau sering digunakan sebagai hiburan masyarakat, pendidikan, dan pengiring tari. Selain perubahan tersebut, perubahan pada kesenian Mantau ini juga terjadi pada pelaku kesenian itu sendiri. Mantau hanya dinyanyikan oleh satu orang saja tanpa ada alat musik sebagai pengiring, sekarang sudah ada kesenian Mantau yang dibawakan oleh dua orang atau lebih. (Daswaredi, Wawancara, Februari 2016, Bangko).

Saat ini Mantau sudah mulai mengalami perkembangan dengan menghadirkan sejumlah alat musik lain seperti; accordion, gendang, gong dan kelintang kayu. Instrumen tersebut kemudian berfungsi sebagai pengiring vokal yang sebelumnya tidak ada pada kesenian Mantau tanpa menghilangkan nilai-nilai tradisinya. Hal ini menjadikan kesenian Mantau tetap hidup dan berkembang sampai sekarang. Dapat juga di telusuri bahwa adanya nilai kreatif dari para seniman tradisi dalam mempertahanan kesenian Mantau.

Kesenian Mantau tidak mempunyai ritme yang baku, ritme tersebut bisa saja berubahubah tergantung si pelaku membawakan, ritme pada Mantau ini terus beulang-ulang, namun rasa musikal Mantau dalam hal perjalanan melodinya tetap terasa. Pada permulaan lagu, melodi Mantau dinyanyikan pada wilayah nada tinggi, kemudian turun hingga satu oktaf (slur), setelah gerak melodi berada pada oktaf bawah barulah teks pantun dinyanyikan. Pergerakan melodi akan lebih terasa dengan aksentuasi yang merupakan ciri khas dalam kesenian Mantau, karena tanpa adanya aksentuasi tersebut, maksud dan tujuan dari Mantau tidak akan sampai kepada siapa yang dituju.

Berdasarkan fenomena pada naynian tradisional Mantau, menjadi pendorong pengkarya untuk mengangkat dalam bentuk wujud karya komposisi musik orkestra dan selakigus sebagai pelestarian kesenian tersebut. Tema melodi pokok yang menjadi ide garapan yaitu diambil dari nyanyian tradisional Mantau dapat dilihat sebagai berikut.

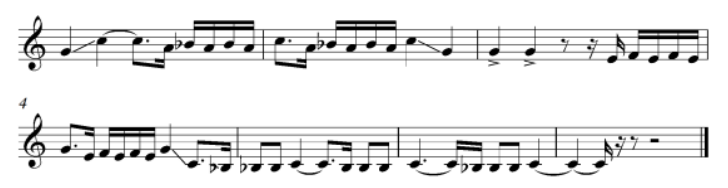

Notasi 1.

Tema melodi "Mantau"

(Transkip, Ana Dilla Putri)

Dilihat pada gambaran notasi dari data transkip di atas, maka dapatlah pengkarya jelaskan bahwa jarak dari setiap interval yang tertulis pada notasi tersebut memiliki kedekatan dengan tangga nada 
Miksolidian seperti berikut, C-D-E-F-G$\mathrm{A}-\mathrm{Bb}-\mathrm{C}$ atau Mixolidyan modes. Namun demikian, dalam penggarapan komposisi Mantau pengkarya tidak menutup kemungkinan untuk menggunakan tanga nada lainnya.

Berdasarkan penjelasan di atas, maka rumusan penciptaan adalah sebagai berikut: "bagaimana menerapkan tematik nyanyian Mantau di Kabupaten Merangin Provinsi Jambi, ke dalam pengolahan komposisi music dalam bentuk lagu dua bagian dengan format orkestra".

\section{METODE DAN PROSES PENCIPTAAN}

Proses penciptaan pada umumnya bersifat sangat subjektif, namun dari sifat tersebut setiap kreator mempunyai pertimbangan tertentu untuk mewujudkan relasi antara ide dan konsep yang disesuaikan dengan penetapan awal.

Karya ini dibuat dengan melakukan beberapa tahapan proses yakni:

a. Preparasi (Tahap persiapan)

Tahap persiapan dimulai dengan mengumpulkan data dan informasi yang berhubungan dengan karya yang penulis buat. Lalu semua data dianalisis untuk menjawab semua kebutuhan dalam penggarapan karya.

b. Tahap Iluminasi

Pada tahap ini sudah mulai menemukan inspirasi atau gagasan serta serangkaian pengertian yang akan digunakan dalam proses penggarapan dengan mulai menentukan yang akan digunakan dalam menggarap karya. Proses ini adalah langkah untuk menentukan dan menyusun idiom musik tradisional ke dalam beberapa bentuk yang disusun secara teknis. Susunan tersebut meliputi pembentukan motif, melodi, frase, polimetrik, sehingga memperjelas struktur bentuk yang dapat dijadikan sebagai penggarapan musik.

c. Tahap Proses Penciptaan

1. Ide dan Gagasan

Mendapatkan motif dari nyanyian tradisional Mantau yang akan dijadikan tema pokok untuk garapan komposisi musik Mantau yang akan diolah dalam format orchestra.

\section{Menentukan Bentuk Komposisi}

Pada penggarapan komposisi Mantau ini, pengkarya memilih untuk memakai bentuk lagu dua bagian. Karena pada material Mantau memang sudah memiliki bentuk lagu dua bagian. Dimana bagian pertama Mantau pertama Mantau bermain dinada yang tinggi, dan bagian kedua vokal Mantau turun satu oktaf (slur).

3. Menentukan Teknik Pengolahan

Pada komposisi Mantau memakai beberapa teknik pengolahan harmoni konsonan, harmoni disonan, mirror harmoni pengolahan secara kontrapung, dan matrical. Tidak hanya itu saja, komposisi musik ini juga menggunakan teknik pengilahan motif di antaranya;

1) Repetisi, teknik pengembangan motif dengan cara mengulang motif atau melodi yang melodi.

2) Sekuen, pengulangan motif atau melodi ditingkat berbeda.

3) Diminusi, teknik pengembangan motif dengan cara penyempitan atau pengurangan nilai nada.

4) Augmentasi, teknik pengembangan motif dengan cara memperluas dan memperpanjang nilai nada.

5) Imitasi, tiruan atau kalimat yang merupakan peniruan dari kalimat.

4. Mengolah materi dan menjadikan Score, menggunakan media komputer dengan software musik Sibelius 7.

5. Tahap Penyajian

Pemilihan alat musik dan elemen-elemen musik yang dipergunakan dalam membuat suatu karya diharapkan dapat menjadikan penonton mengerti dan memahami makana yang tergandung dalam karya ini. Karya ini disajkan dengan formasi orchestra dalam bentuk lagu dua bagian dengan menggabungkan alat musik barat serta alat musik tradisi Mantau itu sendiri. 


\section{HASIL DAN PEMBAHASAN}

Kesenian Mantau merupakan salah satu kesenian tradisi yang tumbuh dan berkembang di daerah Kecamatan Bangko Kabupaten Merangin Provinsi Jambi yang berbentuk nyanyian atau vokal tradisional yang dibawakan oleh satu orang penyanyi. Selain mempunyai kemampuan vokal yang mempuni, penyanyi Mantau mesti memiliki kemampuan dalam menyampaikan syairsyair lagu yang tersusun dalam bentuk pantun secara spontan sesuai dengan keadaan atau kejadian setempat. Oleh demikian, maka kemampuan bernyanyi dan spontanitas berpantun menjadi tuntutan tersendiri bagi seorang penyanyi di dalam kesenian Mantau.

Mantau pada dasarnya memiliki ciri khas yang tergambar pada isi syair Mantau yang lebih cenderung menceritakan kejadian orang lain atau lebih kepada hubungan sosial masyarakat. Ditinjau dari aspek musikal dapat digambarkan juga bahwa terdapat aksentuasi-aksentuasi yang dibawakan oleh penyanyi Mantau, tepatnya sebelum teks pantun dinyanyikan.

Dahulunya, masyarakat Bangko menjadikan Mantau sebagai hiburan yang dinikmati secara pribadi. Namun seiring perkembangan zaman, Mantau mengalami perubahan. Saat ini Mantau sering digunakan sebagai hiburan masyarakat, pendidikan, dan pengiring tari. Selain perubahan tersebut, perubahan pada kesenian Mantau ini juga terjadi pada pelaku kesenian itu sendiri. Mantau hanya dinyanyikan oleh satu orang saja tanpa ada alat musik sebagai pengiring, sekarang sudah ada kesenian Mantau yang dibawakan oleh dua orang atau lebih. (Daswaredi, Wawancara, Februari 2016, Bangko).

Saat ini Mantau sudah mulai mengalami perkembangan dengan menghadirkan sejumlah alat musik lain seperti; accordion, gendang, gong dan kelintang kayu. Instrumen tersebut kemudian berfungsi sebagai pengiring vokal yang sebelumnya tidak ada pada kesenian Mantau tanpa menghilangkan nilai-nilai tradisinya. Hal ini menjadikan kesenian Mantau tetap hidup dan berkembang sampai sekarang. Dapat juga di telusuri bahwa adanya nilai kreatif dari para seniman tradisi dalam mempertahanan kesenian Mantau.

Kesenian Mantau tidak mempunyai ritme yang baku, ritme tersebut bisa saja berubahubah tergantung si pelaku membawakan, ritme pada Mantau ini terus beulang-ulang, namun rasa musikal Mantau dalam hal perjalanan melodinya tetap terasa. Pada permulaan lagu, melodi Mantau dinyanyikan pada wilayah nada tinggi, kemudian turun hingga satu oktaf (slur), setelah gerak melodi berada pada oktaf bawah barulah teks pantun dinyanyikan. Pergerakan melodi akan lebih terasa dengan aksentuasi yang merupakan ciri khas dalam kesenian Mantau, karena tanpa adanya aksentuasi tersebut, maksud dan tujuan dari Mantau tidak akan sampai kepada siapa yang dituju.

Berdasarkan fenomena pada naynian tradisional Mantau, menjadi pendorong pengkarya untuk mengangkat dalam bentuk wujud karya komposisi musik orkestra dan selakigus sebagai pelestarian kesenian tersebut. Tema melodi pokok yang menjadi ide garapan yaitu diambil dari nyanyian tradisional Mantau dapat dilihat sebagai berikut.

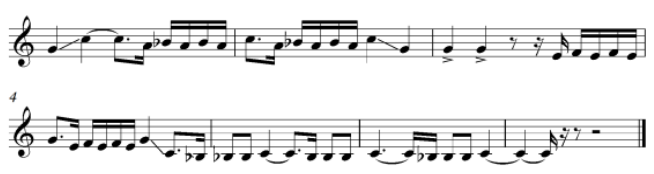

Notasi 1.

Tema melodi "Mantau"

(Transkip, Ana Dilla Putri)

Dilihat pada gambaran notasi dari data transkip di atas, maka dapatlah pengkarya jelaskan bahwa jarak dari setiap interval yang tertulis pada notasi tersebut memiliki kedekatan dengan tangga nada Miksolidian seperti berikut, C-D-E-F-G-A$\mathrm{Bb}-\mathrm{C}$ atau Mixolidyan modes. Namun 
demikian, dalam penggarapan komposisi Mantau pengkarya tidak menutup kemungkinan untuk menggunakan tanga nada lainnya.

\section{Ide Penciptaan}

Berdasarkan pemaran sebelumnya, penulis terinspirasi untuk menciptakan suatu karya yang dapat menyampaikan tentang penerapan tematik nyanyian Mantau yang disusun lagu 2 bagian dalam format musik orkestra. Menggunakan konsep musik tonal yaitu, penggunaan harmoni dan ritme yang bervariasi.

Pada tahapan ini penulis berupaya untuk mendapatkan garapan yang mana tema pokok masih terasa berjalan meskipun tema tersebut sudah di variasikan melalui teknik pengolahan motif.

Penciptaan karya ini memiliki dua tahapan proses yang dilakukan yaitu:

a. Membuat karya yang dilakukan melalui elemen-elemen musik dalam wilayah tonal seperti konsep motif melodi, konsep harmoni, konsep dinaik dan konsep timbre sehingga dapat ditransformasikan sesuai dengan ide penulis.

b. Membuat abstraksi dari kemungkinan cara-cara dalam mentransformasikan idiom musik tradisional ke dalam garapan musik konvensional.

Memahami paparan tersebut, maka dapat disimpulkan bahwa untuk menemukan ide garapan yang berasal dari idiom musik tradisional perlu mengolah elemen-elemen musik seperti mengolah motif melodi, harmoni (diminusi, augmentasi, inversi, trironus, kwartal, dan lain sebagainya), metrik, poliritmik.

\section{Kajian Sumber Penciptaan}

Dalam proses penciptaan komposisi musik ini, penulis mengumpulkan beberapa reverensi, wawancara dengan beberapa seniman tradisional dan dokumentasi serta audio-visual tentang Mantau.

Serta sumber penciptaan karya ini mengacu pada pengalaman pribadi penulis dalam mengamati beberapa karya dan mempelajari buku-buku tentang musik. Ada beberapa karya tentang penciptaan musik yang berasal dari idiom musik tradisional yang sudah dibuat dengan menggunakan berbagai jenis media garap, musik dan format instrumen.

Memahami paparan tersebut, maka dapat disimpulkan bahwa untuk menemukan ide garapan yang berasal dari idiom musik tradisional, perlu mengolah elemen-elemen musik seperti mengolah motif melodi, harmoni (diminusi, augmentasi, inversi, tritonus, kwartal, dan lain sebagainya), metrik, poliritmik.

\section{Tinjauan Karya}

Karya-karya yang berangkat dari kesenian tradisional sudah pernah digarap oleh beberapa pengkarya terdahulu. Salah satu diantaranya Ahma Zaidi pada tahun 2016, membuat komposisi musik karawitan dengan judul karya "Sentak Membumbung". Komposisi ini juga berangkat dari kesenian Mantau, kemudian dikembangkan menjadi sebuah komposisi musik karawitan. Komposisi Mantau ini berangkat dari sepenggal motif Mantau yang terdapat di Kab. Merangin, Jambi. Dan di komposisikan menjadi musik tiga bagian dalam musik karawitan. Yang menjadikan perbedaan dalam penggarapan komposisi ini iadalah, pada karya entak Membumbung'ini dalam proses penggarapannya tidak menggunakan socre, landasan teorinya berbeda dengan ilmu musik konvensional serta berbeda dalam format penggarapannya.

\section{Gagasan ide karya}

Ide karya ini pada dasarnya diambil dari motif melodi Mantau yang dijadikan tema pokok dalam komposisi Mantau Upaya tersebut dapat menjadikan komposisi ini sebagai usaha pelestarian seni tradisi dalam bentuk bary. Hal tersebut sesuai dengan 
pendapat Suka Hardjana "Kesenian tradisional dapat menjadi sumber inspirasi atau sumber kreativitas bagi musisi untuk menciptakan musik yang lebih menarik. Keseimbangan proses inilah yang membuat seni tradisional tersebut selalu menemukan nilai-nilai bangsa" (Suka Hardjana, 2004:64).

Penerapan tematik komposisi Mantau yang dijadikan tema pokok dapat dilihat pada notasi berikut:

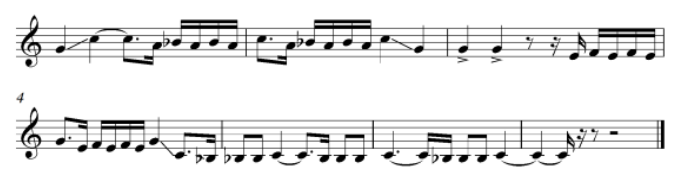

Notasi 1:

Tema Pokok Mantau.

Berdasarkan gambaran notasi dari data transkip di atas, maka dapatlah penulis jelaskan bahwa jarak setiap interval yang tertulis pada notasi tersebut memiliki kedekatan dengan tangga nada mixolidyan modes seperti berikut, C-D-E-F-G-A-Bb-C. Namun demikian, dalam penggarapan komposisi Mantau, pengkarya tidak menutup kemungkinan untuk menggunakan tangga nada lainnya.

Tema pokok komposisi ini digunakan berdasarkan potongan tema dari nyanyian Mantau dan dibuat dalam bentuk lagu dua bagian dengan formasi orkestra. Selain beberapa hal yang menjadi ide pengembangan dan pengolahan tema Mantau, yakni:

\section{Modus Mixolidyan}

Menurut Persichetti "sebuah nada pusat yang berhubungan dengan nada lain dapat membentuk tonalitas, dan cara penempatan nada lain di sekitar nada sentral menghasilkan modalitas. Sebagian besar dari pola tangga nada (scale pattern) telah digunakan oleh para kmposer abad ke-dua puluh, tetapi tujuh di antaranya lebih khusu dari yang lain karena penggunaan whole-halfstep mereka" .

\footnotetext{
${ }^{1}$ Vincent Persichetti, Twentieth Century Harmony (USA: Vail-Ballou Press, Inc., 1978),31.
}

Masing-masing modus memiliki karakter khusus, dan nada apapun dapat digunakan titik tonal awal, dan itulah yang disebut dengan modes (modus). Salah saru diantara tujug modus itu diaplikasikan di dalam komposisi Mantau ini, yakni modus C mixolidyan.

Pada modus mixolidyan dengan karakteristik second-step (natural minot dengan nada ke dua yang diturunkan) memiliki primary chords I, V, VII dan secondary chords ii, IV,vi serta diminised chord pada chord iiio2 $^{2}$. Berikut adalah $\mathrm{C}$ mixolidyan dengan ciri rasa pada $2^{\text {nd }}$ step:

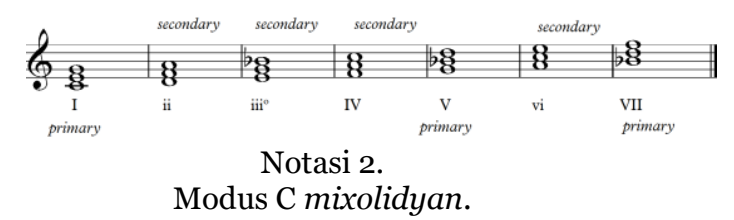

\section{Chord by second}

Menurut Persichetti, mayor dan minor second keduanya bisa dugunakan dalam membangun sebuah chord by second (penggunaan augmented second akan berefek triad). Ada empat tipe interval dari akord three-note by second; mayor-mayor, mayorminor, minor-mayor, dan minor-minor. 3 Disusun berdasarkan progresi konsonan ke disonan yakni:

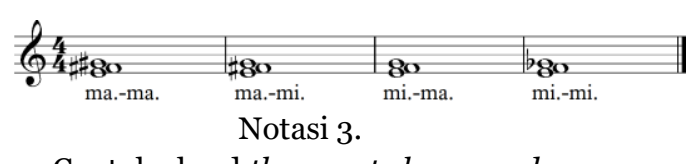

Contoh akord three-note by second.

\section{Chromatic scale}

Chromatic scale menyebabkan terbaginya octave menjadi dua belas langkah. Digunakan sebagai ornamentasi dari dianotic scale, atau sebagai sebuah tangga nada independen (dodecuple) dengan dua belas langkah nada yang sama pentingnya. ${ }^{4}$ Di dalam beberapa

\footnotetext{
2 Vincent Persichetti, 1978,32. 3

4 $121-122$ 60
} 
kasus hanya harmoni atau hanya melodinya saja yang kromatik, sedangkan di kasus lain malah menggunakan keduanya. ${ }^{5}$

Dalam penggunaanya di zaman modern , chromatic menandakan sebuah nada, interval tangga nada atau chord yang menyimpang dengan interval yang kecil (biasanya terdiri dari semitone) dari bentuk khas mayor atau minor; juga sebagai tanda yang mengindikasikan sesuatu seperti penyimpangan; menentang diatonic. Tanda chromatic (aksidental atau chromatics) termasuk sharp (\#), double-sharp (\#\#), flat, double-flatt, natural dan sharp-natural atau flatt-natural, ketika salah satu diantaranya diaplikasikan di dalam tubuh penulisan musik (bukan di tanda mula). ${ }^{6}$

\section{Polymeter}

Penggunaan dua atau lebih tanda sukat secara bersamaan. Ada tiga kemungkinan; tanda sukat yang sama tetapi peletakan yang berbeda; berbeda tanda sukar dengan birama yang sama; dan tanda sukat berbeda dengan birama yang berbeda. $7 \mathrm{Hal}$ ini terjadi pada peletakan titik berat tempo yang berada pada ketukan lemah dari sukar quadruple 4/4 lebih tepatnya pada ketukan kedua dari ssukat 4/4. Dapat dilihat seperti contoh berikut, dimana ">" mengindikasikan aksen, " $\geq$ ” mengindikasikan aksen yang lemah, dan “_” mengindikasikan tidak adanya aksen. Berikut contoh polymeter antara quadruple:

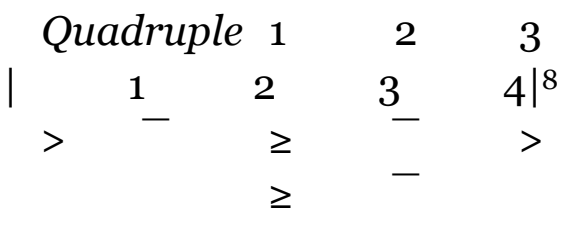

${ }^{5}$ Steven Kotska, Material and Techniques of Twentieth Century Music Third Edition (USA: Pearson Education, Inc., 2006), 34.

${ }^{6}$ Wando Selden Pratt, The New Encyclopedia of Music and Musicians (USA: The Maccmillan

Company, 1923), 27.

${ }^{7}$ Stefan Kotska, 2006: 120.

\section{Ulasan Hasil Komposisi}

Karya ini diberi judul Mantau yang berasal dari idiom musik tradisional yang mana tematik nyanyian Mantau menjadi materi garap utamanya. Komposisi Mantau digarap dengan membutuhkan 4 section intrumen pada orchestra yaitu;

1. Woodwind; Flute, Oboe, Clarinet in Bb, dan Basson.

2. Brass Section; Alto Saxophone, Bariton Saxophone, Horn in $F$, Trumpet in Bb, dan Ttombone.

3. String Section; Violin $1^{\text {st }}$, Violin $2^{\text {nd }}$, Viola, Cello, Contra Bass

4. Percussion non harmonis; Triangle. Grand cassa, Snare Drum, Cymbal dan Chinese Gong .

5. Percussion harmonis; Marimba, Vibraphone, Timpani.

6. Choir; Sopran, Alto, Tenor dan Bass.

7. Etnich Music; Kulintang Kayu, Gendang Melayu, Gendang Ketindik, Gong, Canang, dan Akordion.

Penjelasan bagian-bagian komposisi Mantau telah diuraikan dengan cara mendeskripsikan analisis dengan condence score yang merupakan dasar dari penggarapan orkestrasi. Berikut deskripsi sajian secara singkat akan diuraikan sebagai berikut:

Pada bagian I, diawali dengan potongan tema yang di ambil dari tema Vokal Mantau dengan memakai beberapa kord dan mengolah tema pokok dengan menggunakan beberapa pengembangan motif, seperti imitasi, sequen, augmentasi, dan diminusi, minimakus, dan retrograde. Dengan perjalanan chord I/VII/I/VII/I/VII/II/II/I. Berikut notasi tema pokok bagian I. 


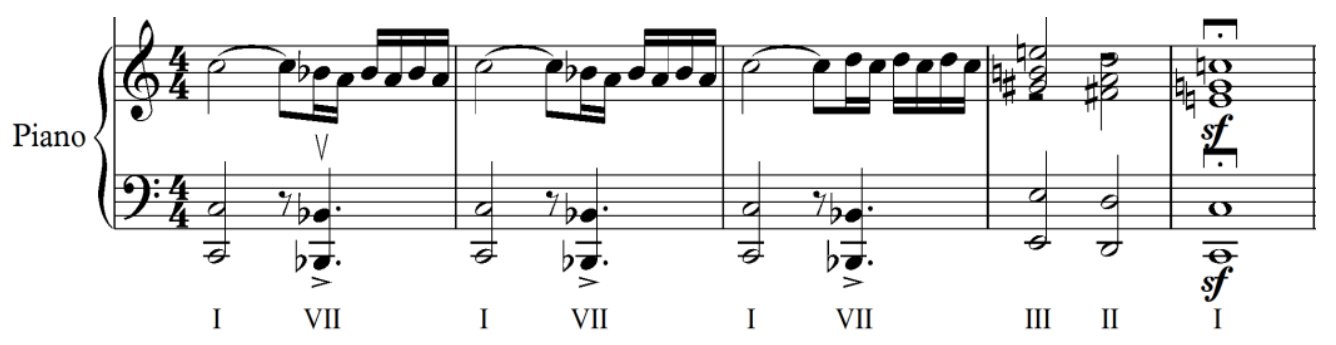

Notasi 2.

Tema bagian I.

Bagian I terdiri dari 115 birama dengan bentuk struktur A (a, b, b' + T + c, c', a, a" + codetta), dimainkan dengan tempo Adante dalam tanda sukat 4/4 serta mengaplikasikan teknik metrical daiantarnya sukat $3 / 8,5 / 8$ dan 6/8 dan dalam tempo Moderatto dalam tanda sukat 4/4, pada tangga nada C mixolidyan dan E mixolidyan. Pada bagian I ini, pengkarya menggabungkan pentatonic scale pengembangan tema bagian a sebagai tema pada bagian transisi.

Pada tema a, pengkarya menghadirkan potongan tema melodi Mantau dimana bagian ini juga dimaksudkan sebagai Introduction. Tema ini terdiri dari 14 birama dan menggunakan materials modes $\mathrm{C}$ mixolidyan, bermain dalam sukat 4/4 dengan tempo andante. Tema melodi Mantau dimainkan oleh instrumen Horn in $F$ (birama 1-5) dan pada birama selanjutnya tema melodi sudah dikembangkan menggunakan teknik imitasi, dimainkan dengan instrumen Trumpet in Bb (birama 6-9).

Selanjutnya pada birama 10-14, pengkarya mengolah harmoni dan menghadirkan identitas achord pada intro ini dimana kord I dan VII merupakan primary achord dari mixolidyan modes dengan perjalanan chord yaitu: I/VII/I/VII/I/VII/III/II/I. Secara rinci, intro jenis ini biasanya terdiri dari pembukaan sebuah pola musik pengiring atau terdiri dari satu chord permulaan atau lebih (Leon Stein, Structure and Style 1969:58) yang dibuat berdasarkan harmoni pengiring dari lagu. Selanjutnya pengkarya mengolah tema melodi menggunakan teknik sequen, repeatisi, retrograde, minimalis, augmentasi, dan imitasi.

Pada bagian akhir dari bagian I ini, pengkarya menghadirkan tema awal, namun pengkarya menggunakan teknik modulasi yang semula bermain di tangga nada C mixolidyan ke E mixolidyan.

Pada bagian II menghadirkan tema baru Mantau yang dimainkan dengan menggunakan teknik pengembangan motif, seperti repeatisi, sequen, augmentasi, imitasi, dan canon, interval by second.

Bagian II terdiri dari 115 birama, dengan bentuk struktur B (a, b, c + T + c, a', a" + coda) dimainkan dengan tempo Andante Maestoso, Maestoso dalam tanda sukat 4/4 juga dalam tempo Allegretto dalam tanda sukat 2/4. Pada bagian II, komposisi ini bermain dalam tangga nada A minor dan pengkarya menggunakan modulasi ke tangga nada B minor.

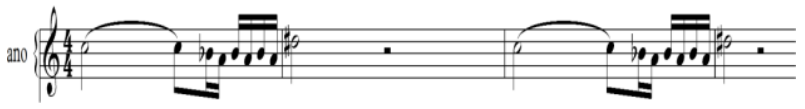

Notasi 3.

Tema pokok bagian II.

Selanjtunya pengkarya mengolah orkestrasi dengan tema yang diolah dengan menggunakan teknik kontrapung yaitu canon yaitu dimainkan oleh Woodwind. Namun pengkarya menghadirkan tema baru dalam bagian II dengan perjalanan chord yaitu; $\mathrm{i}^{2} / \mathrm{III} / \mathrm{IV} / \mathrm{VI}^{3} / \mathrm{V}$. Hal tersebut dapat dilihat pada notasi berikut. 


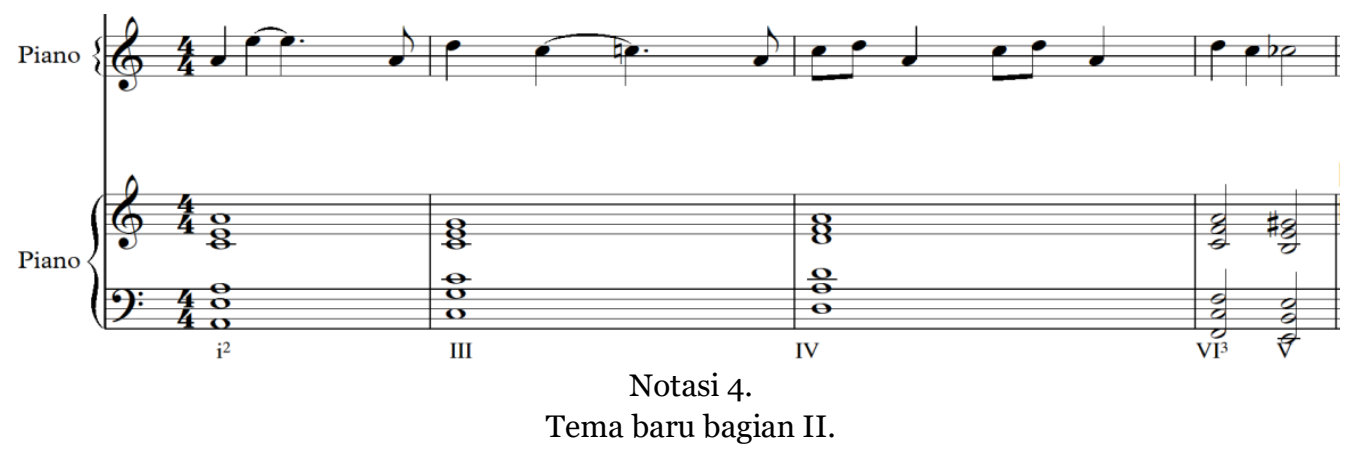

Pada bagian II ini, pengkarya memakai teknik modulasi yang semula bermain dalam tangga nada A minor dan dimodulasikan ke dalam tangga nada B minor. Pengkarya juga menambahkan accelerando (penaikan tempo) guna mengakhiri seluruh rangkaian dari komposisi musik Mantau ini.

\section{KESIMPULAN}

Berdasarkan uraian yang dijelaskan pada bab-bab sebelumnya, maka kesimpulan dari laporan karya seni Mantau adalah sebagai berikut: "bentuk lagu dua bagian mampu diterapkan sebagai salah satu struktur bentuk musik yang menggunakan idiom musik tradisional Mantau kedalam penggarapan kaidah komposisi musik yang berlatar belakang nyanyian tradisi”. Hal tersebut telah diaplikasikan dalam bentuk lagu dua bagian dengan penggabungan format orkestra, alat musik etnis, dan paduan suara.

\section{DAFTAR PUSTAKA}

Apel, Willi. Harvard Dictionary of Music (USA: 1972).

Andreka, Fino. "Komposisi Musik Nyanyian Krinok" Laporan Karya Seni (Institut Seni Indonesia Padangpanjang, 2011).

Banoe, Pono. Kamus Musik (Yogyakarta: Kanisius, 2003).
Cook, Nicholas. A Guide to Musical Analysis (Oxford Univercity Press, 1994).

Fontaine, Paul. Basic Formal Structure in Music (New York: Meredith Publishing Company, 1967).

Fux, Johann. The Study Counterpoint (New York, London, 1965).

Gunawan, Indra. "Efek Instrumen dan Perkembangan” (Padangpanjang, 2010).

Kennedy, Michael. The Oxford Dictionary of Music New Edition. (Oxford University Press. New York, 1994).

Kostka, Stefan. Materials and Techniques of TwenteethCentury Music: Third Edition (New Jersey: Pearson Education, Inc., 2006).

Lovelock, William. Free Counterpoint (Norwick England, 1995).

Ottman, Robert. Elementary Harmony (USA, 1961).

Persichetti, Vincent. Twentieth Century Harmony: Creative Aspect and Practice (USA: Vail-Ballou Press, 1978).

Schoenberg, Arnold. Models for 
Beginners in Composition:

Syllabus and Glossary (U.S.A.:

G. Schirmer, Inc., 1942).

Schoenberg, Arnold. Struktural

Functional of Harmony

(London, 1969).

Selden Pratt, Waldo. The New Encyclopedia of Music and Musicians (USA: The Maccmillan Company, 1924).

Stein, Leon. Structure and Stlye: The Study and Analysis of Musical Forms (USA: Summy-Bichard Music, 1979).

Zaidi, Ahmad. "Komposisi Karawitan Sentak Membumbung" Laporan Karya Seni (Institut Seni Indonesia Padangpanjang, 2016). 